\title{
Chemotherapy sensitivity testing in human tumours
}

\author{
HG RICHMOND AND RW BILLINGTON
}

From the Pathology Department, Raigmore Hospital, Inverness IV2 3UJ, UK

SUMMARY We have attempted to establish in vitro growth in a consecutive series of 245 malignant tumours submitted for routine histopathology. Initially, three disaggregation procedures were used: mechanical separation, digestion by trypsin, and digestion by collagenase. The resulting cell fractions had varying success rates in establishing growth. Abundant epithelial cell growth was achieved in monolayer culture in 63 tumours, and the sensitivity of the cells to cytotoxic agents was tested. There was no indiscriminate cytotoxic effect, and each tumour type varied in its sensitivity from one patient's lesion to another. While testing of all solid tumours is not possible with present-day techniques, we believe that the employment of in vitro sensitivity testing as a routine procedure may be possible in the future if a suitable system giving correlation between in vitro and in vivo sensitivity can be developed.

Since the advent of cytotoxic chemotherapy in the treatment of patients with malignant disease there has been a need for a means of evaluating the response of an individual tumour to any particular drug or combination of drugs. Such a test will pinpoint a likely curative agent, and, at the same time, the harmful effects of inappropriate drugs will be avoided.

Various groups of workers have attempted to tackle this problem, ${ }^{12}$ and some successful correlation between in vitro and in vivo response has been reported. These studies have been carried out in specialised centres, often using sophisticated equipment and highly trained staff. In the present investigation we have enquired into the possibility of extending this type of work to the routine histology laboratory of a district general hospital.

The method of testing was based on a monolayer culture technique, ${ }^{3}$ and thus the first requirement was to establish a system for growing unselected tumour biopsy material in culture. We describe the technique adopted, based on the use of three disaggregation procedures, and discuss the application of the method to a simple cytotoxicity assay.

\section{Material and methods}

Specimens of tumours were obtained from operating theatres at Raigmore Hospital, Inverness, Royal Northern Infirmary, Inverness, Bignold Hospital, Wick, and Lewis Hospital, Stornoway. All types of tumours were studied without selection. The range of tumours is listed in Table 1.

Table 1 Origin of 245 malignant tumours

$\left.\begin{array}{lc}\hline \text { Tissue of origin } & \text { Number of tumours } \\ \hline \text { Breast } & 119(49 \%) \\ \text { Intestine } & 45(18 \%) \\ \text { Fluids } & 18(7 \%) \\ \text { Stomach } & 14(6 \%) \\ \text { Respiratory tract } & 13(5 \%) \\ \text { Ovary } & 7(3 \%) \\ \text { Thyroid } & 6(2 \cdot 5 \%) \\ \text { Kidney } & 5(2 \%) \\ \text { Urinary tract } & 3 \\ \text { Testis } & 1 \\ \text { Uterus } & 1 \\ \text { Gall bladder } & 1 \\ \text { Lymphoid tissue } & 4 \\ \text { Cartilage }+ \text { bone } & 3 \\ \text { Skin } & 4 \\ \text { Adrenal medulla } & 1\end{array}\right\}$

Specimens from Inverness hospitals were collected immediately from theatre. In the pathology laboratory a piece of tissue judged to be from the tumour was removed, adjacent to a block taken for routine histology.

Specimens from outside Inverness were either sent by air, unfixed, or else a portion of tumour was removed in theatre by the surgeon and placed in complete growth medium before being sent by air. Complete growth medium consisted of Medium 199 with Earles Salts with $20 \%$ Foetal Calf Serum and $10 \mu \mathrm{g} / \mathrm{ml}$ insulin, together with antibiotics. The antibiotic mixture included penicillin ( 250 units $/ \mathrm{ml}$ ); 
streptomycin $(250 \mu \mathrm{g} / \mathrm{ml})$; gentamicin $(50 \mu \mathrm{g} / \mathrm{ml})$, and fungizone $(2.5 \mu \mathrm{g} / \mathrm{ml})$. These concentrations of antibiotics were halved once growth had been established.

The tissue was disaggregated by a method combining the techniques of Freshney ${ }^{3}$ and Lasfargues and Ozzello. ${ }^{4}$ From the initial sample, four different cell fractions were produced, one by mechanical means, one by trypsin, and two by collagenase. It was felt that the use of a series of disaggregation techniques should allow the maximum number of tumour cells to be released from the specimen.

The tissue was cut up finely in complete growth medium in a petri dish using crossed scalpels 'scissors fashion'. Care was taken to slice rather than chop the tissue as this leads to extensive cell damage. The pieces obtained (about $2 \mathrm{~mm}$ ) together with the medium were transferred to a universal container and allowed to settle for a few minutes. The supernatant fluid, containing cells spilled out in the cutting process, was carefully removed. The fluid was centrifuged and the cells were suspended in $2 \mathrm{ml}$ of complete growth medium in a Nunc or Falcon $25 \mathrm{~cm}^{2}$ plastic flask.

The pieces were allowed to settle in two further changes of complete growth medium. They were then divided into two portions. The first aliquot was placed in a conical flask containing $0.5 \%$ trypsin in Hanks's Balanced Salt Solution and left overnight at $4^{\circ} \mathrm{C}$. After stirring for 1 hour at $37^{\circ} \mathrm{C}$, the suspension was filtered through gauze and then spun down, the resulting cell pellet being suspended in $2 \mathrm{ml}$ growth medium and set up for culture in a $25 \mathrm{~cm}^{2}$ culture flask.

The second aliquot was taken up in $10 \mathrm{ml}$ complete growth medium containing $1 \mu \mathrm{g} / \mathrm{ml}$ collagenase (Sigma Chemical Co), and $5 \mathrm{ml}$ was distributed into each of two $25 \mathrm{~cm}^{2}$ culture flasks. After 24 to 96 hours' incubation at $37^{\circ} \mathrm{C}$ in an atmosphere of $95 \%$ air $5 \% \mathrm{CO}_{2}$, the flasks were examined for softening and smearing of the pieces of tissue. When this occurred the pieces were drawn up and down in a Pasteur pipette several times, and the resulting suspension was transferred to a universal container and allowed to settle. The supernatant fluid, containing mainly single cells, was removed, and the pieces were washed twice in growth medium. The pieces were then taken up in $5 \mathrm{ml}$ growth medium and transferred to a $25 \mathrm{~cm}^{2}$ culture flask. The pooled supernatants were centrifuged, and the cell pellet was resuspended in $2 \mathrm{ml}$ growth medium and placed directly into a $25 \mathrm{~cm}^{2}$ flask or, occasionally, into the wells of a Falcon Microtest II multi-well plate.

Flasks were examined daily using an inverted phase contrast microscope. The first change observed was either the attachment of cells to the base of the flask, or the appearance of highly refractile clumps of cells floating in the medium. Initially, the medium was changed infrequently, and only when indicated by a lowering of $\mathrm{pH}$. As growth became established, the concentration of antibiotics was halved, and the medium was changed every week. When cultures became confluent, they were passaged after trypsinisation or mechanical removal by a rubber policeman. At this stage all successful flasks were combined regardless of the method of disaggregation.

The cells were classified morphologically from their microscopic appearance under phase contrast as of 'epithelial' or 'fibroblast' type. Only 'epithelial' cell cultures were considered suitable for cytotoxic drug testing.

When cells were judged to be suitable for testing an aliquot was plated into a $5 \mathrm{~cm}$ disposable petri dish containing a $22 \times 22 \mathrm{~cm}$ No. 3 coverslip. They were incubated in medium in a humidified chamber (sandwich box) containing $95 \%$ air $5 \% \mathrm{CO}_{2}$. The cells growing on the coverslip were fixed in Sanfelice's fixative, stained with haematoxylin and eosin, and mounted on a slide using DPX or Canada balsam. A variety of other special stains were occasionally used to correlate in vitro appearances with routine histology.

\section{IN VITRO CYTOXICITY TESTING}

Cells were plated into Falcon Microtest II multi-well plates at a density of 5-15000/well. Up to 96 replicate cultures were set up in the wells of the Microtest plate and, after growth was seen to be well established, the drugs to be tested were added to wells in a random fashion. Each drug was added to five wells, five control wells receiving medium only. The drug concentrations selected were an attempt to reproduce those found in vivo at the site of the tumour. ${ }^{5}$ The average daily dose per kilogram body weight was expressed on the assumption that a kilogram of body weight is equivalent to 1 litre of water. The concentrations used compared quite closely with those arrived at by other workers ${ }^{7}$ and are shown in Table 2 .

Cultures were incubated in the presence of drugs

Table 2 Drug concentrations used

\begin{tabular}{|c|c|c|c|}
\hline Drug & $\begin{array}{l}\text { Concentration } \\
(\mu \mathrm{g} / \mathrm{ml})\end{array}$ & Drug & $\begin{array}{l}\text { Concentration } \\
(\mu g / m l)\end{array}$ \\
\hline Actinomycin D & 0.15 & 6 Mercaptopurine & $7 \cdot 5$ \\
\hline Adriamycin & 5 & Methotrexate & $1 \cdot 5$ \\
\hline Bleomycin & $1 \cdot 5$ & Mithramycin & $0 \cdot 1$ \\
\hline Chlorambucil & $0 \cdot 6$ & Mustine & 0.3 \\
\hline $\begin{array}{l}\text { arabinoside } \\
\text { arasine }\end{array}$ & 6 & Streptozotocin & 25 \\
\hline Daunorubicin & 3 & Thiotepa & 3 \\
\hline 5 Fluorouracil & 45 & Vinblastine & 0.6 \\
\hline $\begin{array}{l}\text { Hydroxyurea } \\
\text { Melphalan }\end{array}$ & $\begin{array}{c}25 \\
0 \cdot 3\end{array}$ & Vincristine & 0.15 \\
\hline
\end{tabular}


for 18 to 24 hours. Drugs were then washed out with three changes of medium, and the cells were grown in medium only for three to four days to allow recovery, if any, to occur. All attached cells were assumed to be viable for the purpose of the test.

The plastic-adherent cells in each well were then counted after trypsinisation, using a Fuchs-Rosenthal counting chamber. The number of cells from each treatment was compared with that from control wells. Any treatments giving a significantly lower mean by analysis of variance $(P<0.05)$ were considered to be effective for that tumour. In practice, this normally involved a reduction in cell numbers of at least $50 \%$ compared with control wells.

\section{Results and discussion}

From Table 1 it can be seen that breast and gastrointestinal tumours predominate in the study, reflecting the surgery carried out in the area.

\section{TUMOUR GROWTH}

Figure 1 traces the development of our culture technique during a period of time in which $\mathbf{3 8 0}$ tumours were examined. The great majority were carcinomata, and their successful growth was graded as follows:

Grade 1 Cells of any type became attached to the base of the culture flask.

Grade 2 Some of the cells were 'epithelial' type.

Grade 3 'Epithelial' cells predominated in the culture, and sufficient growth was achieved to allow a drug sensitivity test to be carried out.

It can be seen that grades 1 and 2 growth increased from tumour 61 onwards. Microbial contamination was markedly decreased after the 60th specimen, and the overall proportion of tumours giving suitable growth for drug testing increased throughout the period being studied. Specimen 60 marks the introduction of the collagenase disaggregation technique, and specimen 121 represents the introduction of insulin as a standard component of the medium. While these technical changes have undoubtedly played a major part in the increased rate of success, increasing expertise in handling the cells is a significant factor.

One of the major problems when using monolayer cultures as the basis of chemotherapy testing is identification of the cells as being 'tumour' cells or otherwise. We have used the criterion of epithelial or fibroblastic morphology in common with most other workers in the field. We assume that cells of 'fibroblastic' morphology constitute normal stromal cells from the tumour, while epithelial cells are considered to be of tumour origin, bearing in mind the known

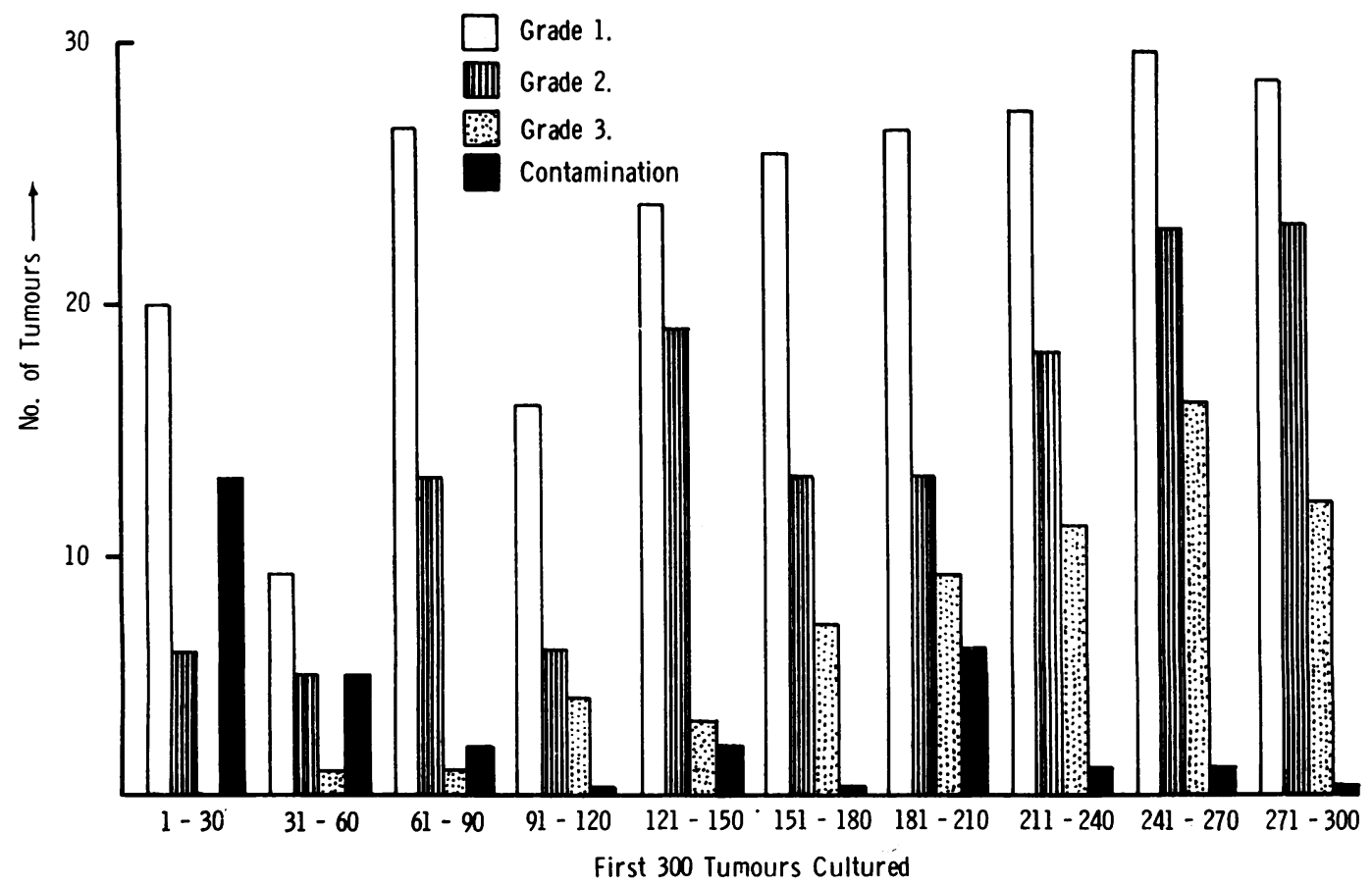

Fig. 1 Grades of growth and microbial contamination in first 300 tumours cultured. Histograms are for groups of 30 tumours in chronological sequence. 
histology of a piece of tumour adjacent to that taken for culture. This view is supported by three strands of evidence: $(a)$ where special staining has revealed characteristic tumour cell constituents, eg, melanin granules in melanoma cells, and glycogen in cells from a clear cell carcinoma of the kidney; (b) cytogenetic studies on fibroblast predominant cultures have shown them to have a normal karyotype while an abnormal chromosomal complement has been demonstrated in mixed growths; $(c)$ in a few tumours electron microscopy has been useful in delineating the cell type cultured. We have therefore used the morphological appearance of the cells as the distinguishing feature, recognising at the same time that an absolute identification of malignancy cannot be made.

Since the collagenase dispersal technique was adopted we have had 245 tumours. Table 3 shows the number of times each grade of growth was established in the various tumours. Out of the 245 specimens, $63(26 \%)$ had a high enough proportion of tumour cells for a drug sensitivity test to be carried out (grade 3 growth).

Table 3 Distribution of 245 tumours according to origin and grade of growth

\begin{tabular}{|c|c|c|c|c|}
\hline \multirow{2}{*}{$\begin{array}{l}\text { Tissue of } \\
\text { origin }\end{array}$} & \multirow{2}{*}{$\begin{array}{l}\text { Total No. } \\
\text { of tumours }\end{array}$} & \multicolumn{3}{|l|}{ Growth } \\
\hline & & Grade 1 & Grade 2 & Grade 3 \\
\hline Breast & 119 & 112 & 86 & 42 \\
\hline Intestine & 45 & 38 & 12 & 2 \\
\hline Fluids & 18 & 5 & 1 & 1 \\
\hline Stomach & 14 & 12 & 3 & 3 \\
\hline Respiratory tract & 13 & 13 & 11 & 2 \\
\hline Ovary & 7 & 7 & 6 & 3 \\
\hline Thyroid & 6 & 6 & 4 & 2 \\
\hline Kidney & 5 & 5 & 5 & 4 \\
\hline Urinary tract & 3 & 3 & 1 & 1 \\
\hline Testis & 1 & 1 & 1 & 0 \\
\hline Uterus & 1 & 1 & $i$ & 1 \\
\hline Gall bladder & 1 & 0 & 0 & 0 \\
\hline Lymphoid tissue & 4 & 3 & 2 & 1 \\
\hline Cartilage + bone & 3 & 2 & 1 & 1 \\
\hline Skin & 4 & 2 & 0 & 0 \\
\hline Adrenal medulla & 1 & 1 & 0 & 0 \\
\hline Total & 245 & $211(86 \%)$ & $134(55 \%)$ & $63(26 \%)$ \\
\hline
\end{tabular}

Breast tumours constitute almost half the sample and are among the easier ones to grow, $94 \%$ showing some growth. The 42 drug tests carried out in breast tumours represent $66 \%$ of all drug tests. In common with other workers in the field, we met difficulties with breast tumours. ${ }^{8}$ Even if the tumour cells can be established (grade 2 growth), the contaminating fibroblasts eventually overtake and engulf the tumour cells.

In our hands, tumours of the alimentary tract have proved to be difficult to culture, at least as far as epithelial-type cells are concerned. Although $84 \%$ of intestine and $86 \%$ of stomach tumours establish some cell growth, the vast majority produce fibroblast-type cells only, and in fact only $4 \%$ of intestinal tumours and $21 \%$ of stomach tumours gave suitable growth for cytotoxic drug testing. Just as with breast tumours, the fibroblasts eventually take over the culture flasks.

In terms of the establishment of epithelial cell growth, the most successful tumours are those having the least amount of fibrous stroma. Thus, tumours of respiratory tract and thyroid, and especially those of ovary and kidney, all show a high proportion of grade 2 growth and also of cultures suitable for cytotoxic drug testing. Surprisingly, malignant effusions in which the cells could be simply spun down and placed in medium showed very little success, most of them producing no cell establishment at all. These findings are contrary to most previous results in this field, where effusions have been a major source of cell lines. ${ }^{910}$

\section{DISAGGREGATION}

Our method of disaggregation endeavours to make use of all the available tissue as a source of cells. During the initial cutting up procedure, the cells that were released from the tumour were collected and cultured as the 'spill' fraction. This method was pioneered by Lasfargues and Ozzello 4 and has been extended by Liebovitz et al.,11 who found that spilled out cells were the principal source of successful cultures in most solid tumours, especially in breast tumours. The pieces obtained by chopping are further disaggregated by enzymic means, both trypsin and collagenase being employed for each tumour. The released cells and residual pieces are all placed in flasks for culture.

Figure 2 summarises the proportion of successful cultures established from each stage of the disaggregation procedure. It can be seen that collagenase dispersion is by far the most successful means of producing viable cells. This can be accounted for by the microscopic structure of most of the tumours used. Most are highly scirrhous and consist of a dense network of collagen fibres containing islets of epithelial cells. Trypsin has no effect on the collagen and releases virtually no cells froma scirrhous tumour. Highly cellular ovary and kidney tumours were easily disrupted by the trypsin, although, interestingly enough, the collagenase was equally effective in the tumours where collagen was not present in large amounts. Presumably a small amount of proteolytic activity is present in the collagenase in use.

Relative to collagenase preparations, the spilledout cells show a poor rate of growth establishment. These cells formed the basis for the production of cell lines from breast tumours by Lasfargues, ${ }^{12}$ as they 


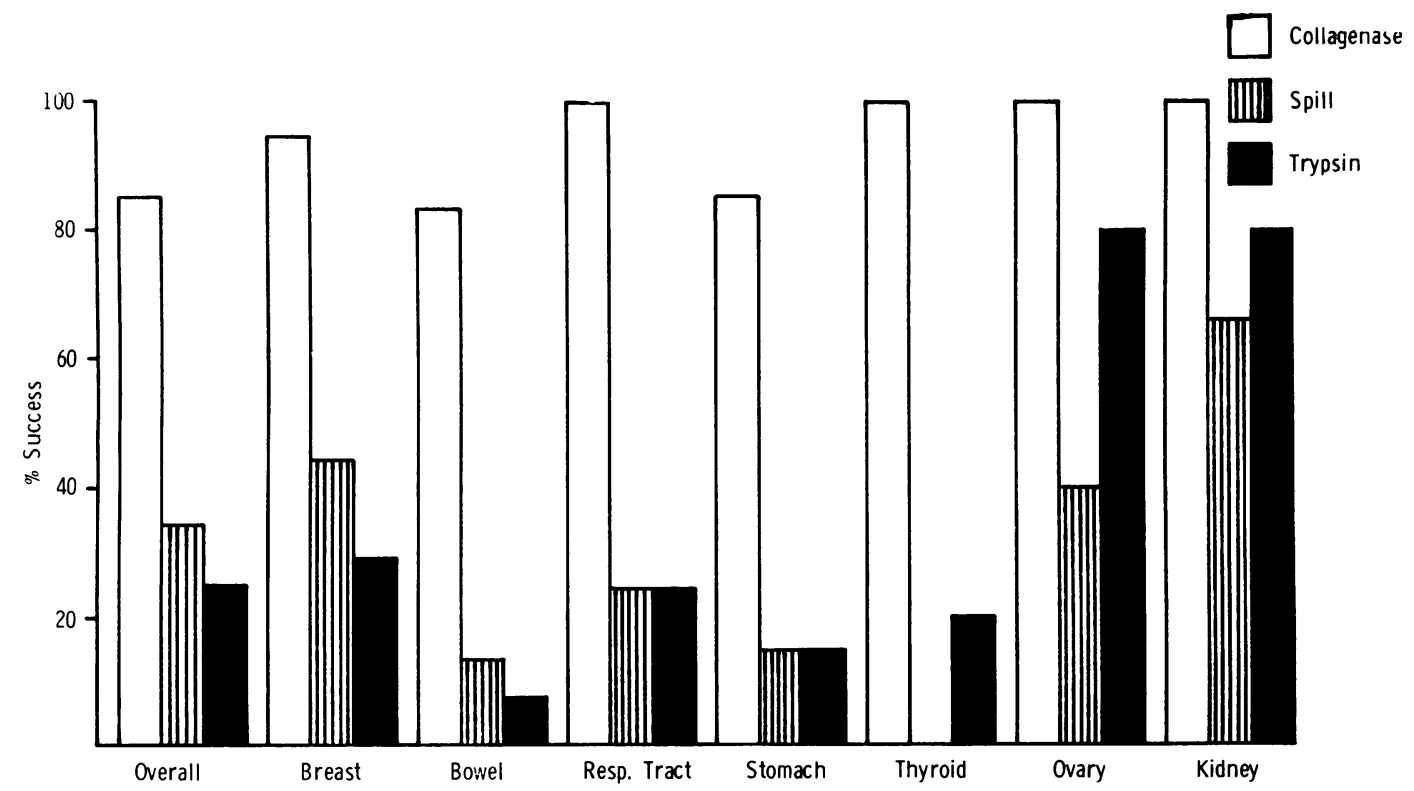

Fig. 2 Successful growth establishment by three disaggregation techniques for different tumour types.

were considered to represent the viable tumour cells, which are released from the fibrous stroma on slicing. Of our breast tumours $47 \%$ produced growth establishment in this way, and the kidney and ovary tumours were also reasonably successful. Thus, while it is obviously worthwhile retaining and culturing this cell fraction, many tumours will require further enzymic disaggregation in order to achieve successful growth of monolayers.

This can be explained by observing how monolayer growth tends to arise in flasks. Almost invariably, growth arises by migration of cells from a small clump, or even quite a large piece of tissue, which has become attached to the base of the flask. It seems to be a very unusual event, certainly in the case of epithelial cells, for a single cell to become attached and subsequently to proliferate. Even in trypsinised preparations where there is a mixture of single cells and small clumps of tissue, it is usually by outgrowth from a piece of tissue, rather than by division of a single cell, that growth is initiated. The 'pieces' fraction left after collagenase digestion will have a number of suitable sized cell clusters for growth. The supernatant fraction, by its very nature, consists mainly of single cells or small groups which sediment only slowly in medium. Once again, however, there are usually enough suitable cell groups to produce growth from the supernatant fraction, as can be seen from Figure 2.
FIBROBLAST OVERGROWTH

Since successful growth arises from groups of cells or pieces of tissue some fibroblast contamination seems inevitable. Pieces of tissue become attached to the plastic substratum of the flask, and if tumour cells are present they usually grow out first on to the base of the flask (Fig. 3). Alternatively, fibroblast and tumour cells grow out simultaneously (Fig. 4). In the case of breast tumours, the epithelial-type cells grow more quickly initially and are the predominant cell type, but eventually the fibroblast population engulfs the tumour cells. A drug sensitivity test can be carried out if tumour cells grow quickly enough within a short time before fibroblasts take over the cultures. Some cultures, notably from highly cellular tumours, are not so rapidly affected by fibroblast overgrowth and may continue as almost pure epithelial cell cultures for many weeks. In the end, however, all cultures succumb to fibroblast predominance.

Various approaches to the problem of fibroblast contamination have been suggested. 8 We have made attempts to separate fibroblasts using Ficoll gradients without success. We have also tried a low concentration of collagenase in the growth medium ${ }^{13}$ but found that using the enzyme at a high enough concentration to inhibit the growth of fibroblasts is equally damaging to epithelial cells. The ultimate solution may lie in producing a medium able to satisfy the exacting requirements of the tumour cells 


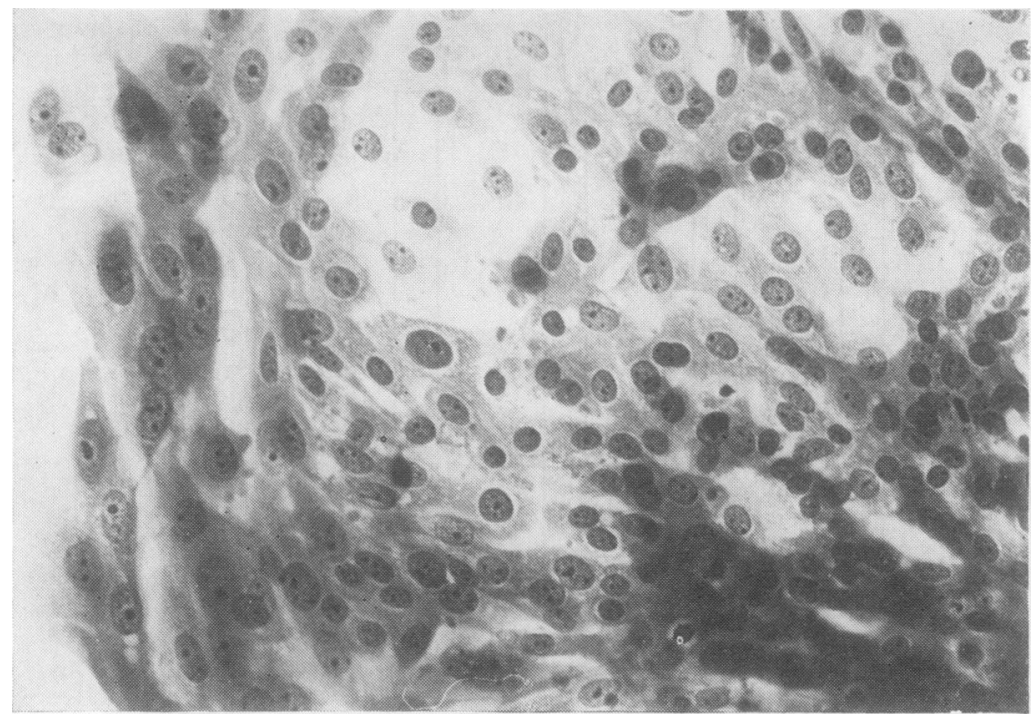

Fig. 3 Outgrowth of epithelial cells from attached fragment, right lower. Haematoxylin and eosin $\times 350$.

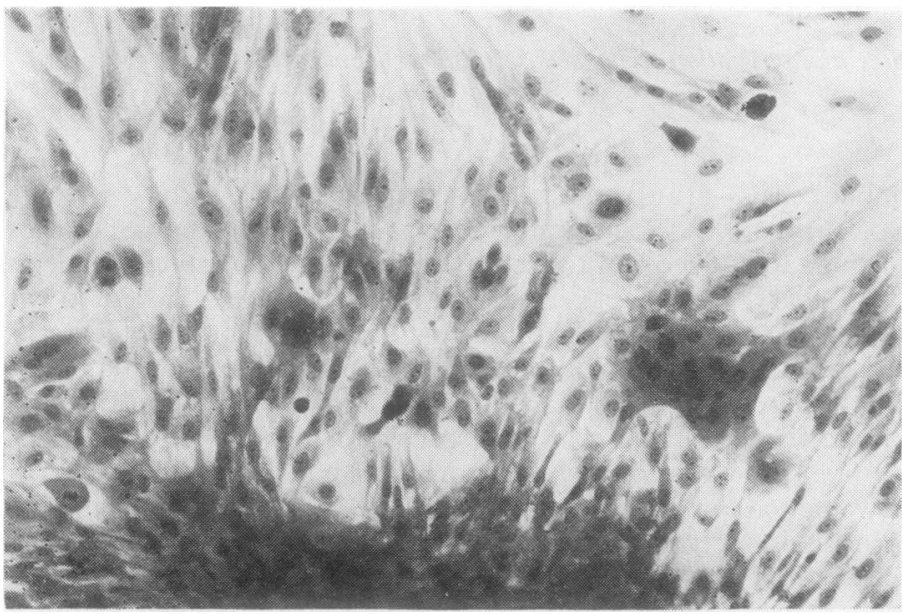

Fig. 4 Mixed fibroblast outgrowth from attached piece of tissue, with a small distinct plaque of epithelial cells on right. Haematoxylin and eosin $\times 140$.

more adequately, thus allowing them to compete on better terms with the ubiquitous fibroblasts.

\section{IN VITRO DRUG SENSITIVITY TESTING}

The method of drug sensitivity testing was based on the monolayer culture techniques most widely used at the time. ${ }^{2}$

The relationship between concentrations of a drug in vivo and in vitro are difficult to establish. The drug concentrations chosen were somewhat arbitrary but were based on considerations of concentration of drug attainable in vitro. The dosage levels were designed to give a measure of the in vitro potential of each drug, at the same time being realistic in terms of the amount of drug that can be given to the patient.
A drug exposure-time of 18-24 hours was selected as that most commonly used by others for cytotoxicity testing. ${ }^{2}$ This may be longer than the exposure time in vivo. Nevertheless, it is a single exposure upon which effectiveness is being judged, as opposed to multiple exposures in most cytotoxic drug regimens.

We chose to use single cell counting of surviving cells as a means of estimating cell death. This measures metabolic as opposed to reproductive death. ${ }^{14}$ The accepted method of estimating reproductive death is colony-forming ability, which depends on the production of single cell suspensions of the tumour. Our main source of material was breast and colon carcinomas in solid form. We found that viable single cell suspensions cannot be made from the 
material, and a similar difficulty was reported by Buick et al. ${ }^{15}$ The use of a three- or four-day recovery period after removal of drugs may go some way towards reducing the discrepancy between metabolic and reproductive death measurements.

A total of 63 specimens had a suitable proportion of tumour cells to allow cytotoxicity testing to be carried out on microtest plate replicate cultures. The drugs tested on each tumour were chosen on the basis of the most common drugs used clinically for the particular tumour type in question. Altogether we tried 17 different drugs, and from five to nine were tested on each microtest plate. Cyclophosphamide could not be used because it needs in vivo activation to produce the anti-tumour metabolite.

Out of the 63 tests, cells showed no sensitivity to any drug tested on 42 occasions $(67 \%)$. Where sensitivity was shown, the number of successful drugs varied between one and eight. The frequency of the number of successful drugs for each tumour is shown in Figure 5. It can be seen that most tumours are

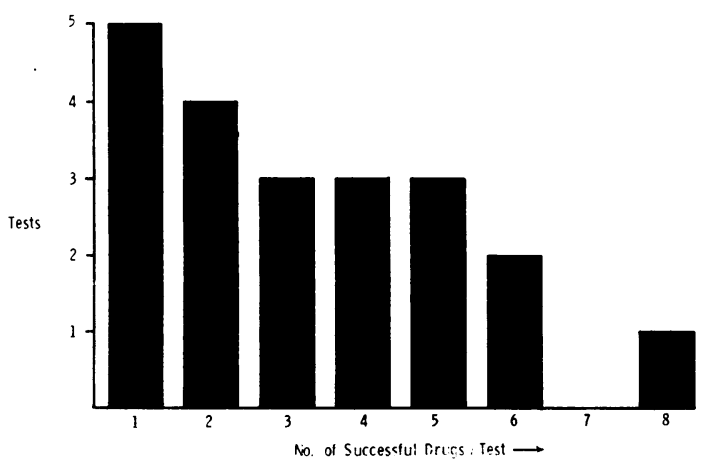

Fig. 5 Number of cell sensitivity tests in which a single drug or a selection of drugs showed significant cell killing.

sensitive to a small number of drugs, only three out of 21 being sensitive to more than five drugs. This suggests that the method used is capable of discriminating between drugs, rather than simply showing a blanket cytotoxic effect. This is further illustrated in Table 4, where the effectiveness of individual drugs is shown on the basis of the number of tests carried out. Actinomycin D is the most potent drug, while most of the others used exhibit a success rate of around $20-30 \%$ with varying effect in different tumours, as illustrated in Table 5, which shows the results of drug tests on three different breast carcinomas.

Table 6 shows the success rate of various agents when tested against cells from cultures of breast carcinoma only. Once again, actinomycin $\mathrm{D}$ is the
Table 4 Effectiveness of drugs; all tumours

\begin{tabular}{llll}
\hline Drug & No. of tests & $\begin{array}{l}\text { No. of times } \\
\text { effective }\end{array}$ & $\%$ \\
\hline Actinomycin D & 18 & 11 & 61 \\
Adriamycin & 35 & 13 & 37 \\
Bleomycin & 13 & 4 & 31 \\
Mustine & 18 & 5 & 28 \\
Chlorambucil & 26 & 7 & 27 \\
5 Fluorouracil & 41 & 11 & 27 \\
Vinblastine & 22 & 5 & 27 \\
Thiotepa & 22 & 6 & 23 \\
Methotrexate & 34 & 4 & 18 \\
Melphalan & 26 & 3 & 13 \\
Vincristine & 23 & & \\
\hline
\end{tabular}

Table 5 Drug tests on three different breast carcinomas

\begin{tabular}{lll}
\hline & Cells sensitive to: & Cells not sensitive to: \\
\hline 1 & Chlorambucil & $\begin{array}{l}\text { Adriamycin, } 5 \text { fluorouracil, } \\
\text { methotrexate } \\
\text { Chlorambucil, adriamycin }\end{array}$ \\
2 & $\begin{array}{l}\text { 5 Fluorouracil, melphalan, } \\
\text { mustine, methotrexate, } \\
\text { actinomycin D, vincristine } \\
\text { Vinblastine, adriamycin, } \\
\text { thiotepa, chlorambucil, } \\
\text { melphalan }\end{array}$ & $\begin{array}{l}\text { Methotrexate, } 5 \text { fluorouracil, } \\
\text { vincristine }\end{array}$ \\
\hline
\end{tabular}

Table 6 Breast tumours

\begin{tabular}{llll}
\hline Drug & No. of tests & $\begin{array}{l}\text { No. of times } \\
\text { effective }\end{array}$ & $\%$ \\
\hline Actinomycin D & 15 & 9 & 60 \\
Vinblastine & 13 & 5 & 38 \\
Adriamycin & 31 & 9 & 29 \\
Chlorambucil & 21 & 6 & 29 \\
5 Fluorouracil & 33 & 8 & 24 \\
Methotrexate & 27 & 5 & 22 \\
Melphalan & 24 & 3 & 21 \\
Mustine & 16 & 3 & 19 \\
Vincristine & 20 & 2 & 12 \\
Thiotepa & 17 & & \\
\hline
\end{tabular}

most prominent, and the greater relative effectiveness of vinblastine in this tumour type is worthy of note.

\section{References}

${ }^{1}$ Hall TC, ed. Prediction of response in cancer therapy. Natl Cancer Inst Monograph 34; Washington DC: US Govt Printing Office, 1976.

a Dendy PP, ed. Human tumours in short term culture. London: Academic Press, 1976.

${ }^{3}$ Freshney RI. Preparation of primary cell cultures. In: PP Dendy, ed. Human tumours in short term culture. London: Academic Press, 1976:20-4.

4 Lasfargues EY, Ozello L. Cultivation of human breast carcinomas. J Natl Cancer Inst 1958;21:1131-47.

${ }^{5}$ Limburg H, Hackman NU. Chemotherapy in the treatment of advanced pelvic malignant disease, with special reference to ovarian cancer. J Obstet Gynaecol Brit Commonwealth 1968;75:1246-55.

- Dendy PP, Bozman UG, Wheeler TK, Dawson MP. In: DC Williams, MH Briggs, ed. Some implications of steroid hormones in cancer. London: Heinemann, 1971: 107. 
7 Dickson JA, Suzangar M. In vitro sensitivity of tumour slices. In: PP Dendy, ed. Human tumours in short term culture. London: Academic Press, 1976:107-38.

${ }^{8}$ Fogh J. Human tumour cells in vitro. New York: Plenum Press, 1975.

9 Pomerat CM, Nowinski WW, Rose GG. Tissue cultures of cells from body fluids. Texas Rep Biol Med 1950;8: $521-32$.

${ }^{10}$ Cailleau R, Young R, Olivé M, Reeves WJ Jr. Breast tumour cell lines from pleural effusions. $J$ Natl Cancer Inst 1974;53:661-74.

${ }^{11}$ Liebovitz A, McCombs WB III, Johnston D, McCoy CE, Stinson JC. New human cancer cell culture lines, I. SW13 small cell carcinoma of the adrenal cortex. $J$ Natl Cancer Inst 1973;51:691-7.

${ }^{12}$ Lasfargues EY. New approaches to the cultivation of human breast carcinomas. In: J Fogh, ed. Human tumour cells in vitro. New York: Plenum Press, 1975:51-77.

${ }^{13}$ Lasfargues EY, Moore DM. A method for the continuous cultivation of mammary epithelium. In Vitro 1971;7:21-5.

${ }^{14}$ Buick RN, Fry SE, Salmon SE. Application of in vitro soft agar techniques for growth of tumour cells to the study of colon cancer. Cancer $1980 ; 45: 1238-42$.

15 Roper PR, Drewinko B. Comparison of in vitro methods to determine drug-induced cell lethality. Cancer Res 1976 $36: 2182-8$.

Requests for reprints to: Dr HG Richmond, Pathology Department, Raigmore Hospital, Inverness IV2 3UJ. 